\title{
ARTIKELEN
}

\section{Risicoprofiling of risicovolle profiling tijdens grenscontroles?}

\author{
Naar een verantwoord gebruik van proactieve risicoprofielen \\ door rechtshandhavingsinstanties
}

Jop Van der Auwera \& Lore Van de Velde

\begin{abstract}
Hoewel risicoprofiling absoluut niet beschouwd kan worden als een 'nieuw' hulpmiddel bij de preventie van criminaliteit, heeft de toepassing ervan de afgelopen jaren toch aan populariteit gewonnen. Zowel bij de screening van asielzoekers, bij de controle aan de grensovergang in luchthavens (o.a. gedragsprofilering of het gebruik van risicoprofielen in de Europese passagiersinformatie-eenheid (PIE)) als bij het aanduiden van hotspots op lokaal niveau (o.a. Criminaliteits Anticipatie Systeem) wordt thans vaker getracht om personen met een criminele intentie te identificeren aan de hand van ordinale risicotaxaties. Die populariteitstoename is op zich niet merkwaardig, aangezien willekeurige politiepatrouilles al langer een verwaarloosbare impact blijken te hebben op de reductie van criminaliteit (zie o.a. Ratcliffe et al., 2011). Preventieve risicoprofielen bezitten daarentegen een zeker potentieel om de interventies van of bewaking en beveiliging door rechtshandhavingsautoriteiten op grensposten doelmatiger en gericht vorm te geven. Niettemin doet het gebruik van zulke profielen ook enkele pertinente vragen rijzen. Precies in het licht van deze ambivalentie zal in voorliggende theoretische bijdrage aan de hand van een gebalanceerd en reflectief overzicht worden stilgestaan bij de aandachtspunten en succesfactoren van de risicoprofiling tijdens grenscontroles, teneinde uit te maken wanneer gesproken kan worden over 'risicoprofiling' en wanneer het concept 'risicovolle profiling' gehanteerd dient te worden.
\end{abstract}

\section{Het nieuwe 'risicoreducerende discours' in de criminaliteitsbestrijding}

Ingegeven door het huidige scala aan beschermende instituties, instellingen en systemen die onze samenleving rijk is (o.a. inkomstenbescherming en brandverzekering), postuleert Castel (2003) dat we sinds de eeuwwisseling leven 'dans des sociétés parmi les plus sûres qui aient jamais existé. Nooit stonden we op technologisch vlak verder dan vandaag, nooit was ons welvaarts- en welzijnsniveau zo hoog, nooit werden we meer verzekerd en beter beschermd tegen gevaren die voortvloeien uit de agressie van andere mensen. Niettemin ervaren we als 'meest ontwikkelde en gemoderniseerde individuen' tóch meer individuele bedreiging, onzekerheid en angst dan ooit tevoren (Bauman, 2013; Castel, 2003). 
Deze maatschappelijke tendens heeft ook een onmiskenbare invloed op ons dagelijks leven. Met enige vorm van overdrijving stellen sociologen dat de laatmoderne burgers het idee hebben dat 'nothing is safe anymore'. Zelfs de meest alledaagse zaken (zoals eten, sporten en vakantie nemen) kunnen als potentieel risicovolle activiteiten worden aanzien (Furedi, 2018). In zo'n samenleving waarin een toegenomen risicobewustzijn gelijktijdig optreedt met een dalende risicoacceptatie, lijken concepten als risicotaxatie, -reductie en -beheersing uit te groeien tot cruciale aandachtspunten (Tierney, 2020). Goed beseffende dat men als kwetsbare burger in de onmogelijkheid verkeert om grootschalige criminaliteitsrisico's eigenhandig te beheersen, richt men zijn veiligheidsverwachtingen rechtstreeks tot de overheid. Deze vraag naar risicoreductie hoort de overheid in te lossen middels een doelgerichte criminaliteitsbestrijding, waarbij in het bijzonder aandacht wordt besteed aan preventieve beveiligingsmaatregelen, zoals onder meer surveillance en profiling (Van der Woude \& Van Sliedregt, 2007). Zo richt het preventieve criminaliteitsbeleid zich eerder op het beperken van gevaren, het verhinderen van schade en het onschadelijk maken van risicovol gedrag, dan op het strafrechtelijk reageren op reeds gepleegde misdrijven. Naast een repressief-reactief antwoord op een strafrechtelijke inbreuk wordt van rechtshandhavingsinstanties immers ook een preventief antwoord verwacht met een specifieke focus op de vroegtijdige detectie van indicatoren die kunnen leiden tot risicovol gedrag (Muller, 2006; Svensson et al., 2011).

Inzake de veranderende visie op criminaliteitsbestrijding heeft Zedner (2007) het over een transitie van een post-crime- naar een pre-crimefocus die gekarakteriseerd wordt door een streven naar maximale veiligheid aan de hand van preventie, bewaking én het veelvuldig berekenen alsook identificeren van toekomstige risico's. Daar waar rechtshandhavingsinstanties zich bij een post-crimefocus hoofdzakelijk bezighielden met het identificeren van de individuele dader, om deze bijgevolg te straffen en te behandelen, richt de pre-crimefocus zich ook op het inschatten van risico's op basis van risk assessment tools die focussen op groepskenmerken. Het mag dan ook niet verbazen dat het criminaliteitsbeleid bij grenscontroles in een pre-crime-samenleving steunt op ruime preventieve opsporingsbevoegdheden en allerhande moderne vooruitziende controle-, detectie- en surveillancemechanismen om dagelijks te anticiperen op mogelijke vormen van criminaliteit, schade en onveiligheid (zie par. 2.3) (Zedner, 2007). Meer concreet wordt aan de hand van allerhande probabilistische methoden getracht om bepaalde groepen doelgericht te identificeren en te classificeren volgens hun kwantificeerbare gevaarlijkheidsniveau (zie o.a. Harcourt, 2007). In die zin heeft de preëmptieve logica alle schijn van een actuariële benadering of risicojustitie, waar naast reële criminaliteit ook bepaalde 'indicatoren' een trigger kunnen vormen om tot actie over te gaan. De breed gedragen ambitie bestaat er namelijk in om via indicatoren in een early interventionmodel vroegtijdig potentieel gevaarlijk gedrag te detecteren, precies om het nadien onschadelijk te maken en criminaliteit te vermijden (of althans de schade ervan te reduceren) (Pleysier, 2012). 


\section{Het potentieel van risicoprofiling tijdens grenscontroles}

\subsection{Een begripsduiding}

De huidige tijdsgeest waarin vroegtijdig signaleren, risicotaxatie en het reduceren van veiligheidsrisico's cruciale aandachtspunten zijn, alsook de toenemende kennis over criminele denkwijzen en allerhande criminaliteitsfenomenen, maken het gebruik van risicoprofiling door opsporingsinstanties het laatste decennia bijzonder populair (Janssen, 2014; Van der Woude \& Van der Leun, 2013). De voorkeur voor risicoprofiling is niet alleen toe te schrijven aan de theoretische potentie om toekomstige criminelen preventief te identificeren, maar ook aan de constante drijfveer van rechtshandhavingsinstanties om hun economische efficiëntie te bevorderen (Harcourt, 2007; Harris, 2002).

Risicoprofielen worden doorgaans inductief vormgegeven, wat in abstracte bewoording betekent dat op basis van verschillende individuele gevallen een generalisatie gemaakt wordt die suggereert dat soortgelijke gebeurtenissen in de toekomst vaak dezelfde gemeenschappelijk kenmerken zullen delen (Hildebrandt, 2008; Petherick \& Turvey, 2011). Concreet wil dit zeggen dat op statistische wijze wordt nagegaan welke verschillende individuele kenmerken en gegevens (zoals fysieke, demografische, psychologische en gedragsmatige eigenschappen) een verband vertonen met historisch criminele data. Enkel de variabelen die een significante correlatie vertonen met crimineel gedrag uit het verleden worden bijgevolg opgenomen in een algemeen risicoprofiel (Brown \& Korff, 2009; Fuster et al., 2010).

\subsection{De 'predictieve' meerwaarde}

De samenstelling van een set risicofactoren, typerend voor personen die in het verleden een bepaald misdrijf hebben gepleegd, bezit enigszins een predictieve waarde. Een gezamenlijke aanwezigheid van meerdere profielkenmerken wordt namelijk verondersteld geassocieerd te zijn met een verhoogde waarschijnlijkheid op het plegen van een delict: hoe meer overeenkomsten met het risicoprofiel, hoe waarschijnlijker een misdrijf zich zal voltrekken - althans in theorie (Harris, 2002; Van der Woude \& Van der Leun, 2013; Whitaker, 2011). Een risicoprofiel kan met andere woorden niet 'voorspellen' of een individu criminaliteit zal plegen, maar wel dat bepaalde (sub)populaties er gemiddeld vaker in geïnteresseerd zijn (Smit et al., 2016). De kerngedachte is immers dat zulke profielen statistisch gezien nog niet nader vertoond crimineel gedrag vroegtijdig kunnen signaleren, zodat opsporingsen beveiligingsdiensten preventief kunnen ingrijpen wanneer ze gericht zoeken naar individuen die gelijkenissen vertonen met de reeks risico-indicatoren (Van der Auwera \& Van Daele, 2019).

Precies omdat de proactieve analyses aanduiden welke (sub)populatie het meeste kans heeft om een misdrijf te plegen, is het voor rechtshandhavingsinstanties mogelijk om doelmatiger en efficiënter te interveniëren (De Vries \& Smit, 2016; Mali, Bronkhorst \& Den Hengst, 2017). Het primaire doel wordt in dat verband vaak omschreven als 'het bekomen van actionable knowledge', waar de verwachtingen voor de toekomst de richtwijzer vormen om interventiebeslissingen te nemen op individueel of groepsniveau (WRR, 2016). Met het oog op de wijdverspreide be- 
hoefte aan budgettaire bezuinigingen op het rechtshandhavingsniveau, lijken risicoprofielen in dit opzicht een bruikbaar kostenefficiënt antwoord aan te reiken (De Vries \& Smit, 2016).

Vooral inzake criminaliteitspreventie, en in het bijzonder tijdens systematische beveiligingscontroles op grensposten (o.a. in luchthavens of treinstations), bezit de techniek een potentieel. Een classificatie naargelang risico of dreiging kan in de praktijk immers een betekenisvolle meerwaarde bieden met het oog op het verlenen van een aangepaste behandeling naar verdachte individuen toe (Fuster et al., 2010; Lyon, 2003). Door de specifieke informatie die een risicoprofiel bevat, is het theoretisch gezien bij machte om een groot aantal personen binair te categoriseren volgens veiligheidsrisico. In dat opzicht wordt volgens Lyon (2003) tegenwoordig aan een vorm van social sorting gedaan, waarbij - volgens een zekere assumptie van wat als 'norm' wordt aanzien in de maatschappij - de bevolking tweeledig wordt ingedeeld in een veilige en een risicovolle(re) subpopulatie. In die optiek wordt gehandeld naargelang de risico-inschatting van een persoon of situatie: 'the higher the risk, the more surveillance' (Peeters \& Schuilenburg, 2018: 276). Door consequent en aan de hand van een gefundeerd risicoprofiel de potentiële high-risk personen uit een omvangrijke en moeilijk te controleren groep te selecteren, bezit men namelijk de theoretische capaciteit om met eenzelfde inspanning een hogere hitrate te bereiken (Van der Woude \& Van der Leun, 2013).

Dit theoretisch potentieel kan echter enkel worden benut in de praktijk, wanneer rechtshandhavingsinstanties die risicoprofielen hanteren voldoende bewust zijn van de belangrijkste valkuilen bij het gebruik ervan (zie par. 3) alsook rekening houden met de noodzakelijke succesfactoren om deze risicoprofielen een zekere duurzame draagwijdte mee te geven (zie par. 4). Om de hitrate op een constant (hoog) niveau te houden, dienen de risicoprofielen minstens te voldoen aan de opgesomde voorwaarden. Indien dit niet het geval is, zullen de meest succesvolle interventies op langere termijn juist minder bruikbaar worden, omwille van het constante aanpassings- en verplaatsingsgedrag van criminelen (zie o.a. Bruinsma et al., 2010).

\subsection{Risicoprofiling tijdens grenscontroles: twee verschillende, doch actuele voorbeelden}

\subsubsection{Verwerking van passagiersgegevens door PIE's}

Teneinde terrorisme en ernstige criminaliteit te voorkomen, verplicht richtlijn 2016/681 ${ }^{1}$ de EU-lidstaten sinds 2016 ertoe om een (nationale) 'passagiersinformatie-eenheid' (PIE) op te richten die de verwerking van passagiersgegevens inzake het internationale vervoer voor haar rekening neemt. In het kader van preventieve criminaliteitsbestrijding betekent dit concreet dat een beoordeling kan plaatsvinden van de passagier (op basis van de passagiersgegevens) alvorens deze gebruikmaakt van het internationale vervoer (en aldus op de luchthaven arriveert). Die beoordeling steunt daarbij op twee krachtlijnen: enerzijds zoekt de PIE naar

1 Richtlijn (EU) 2016/681 van het Europees Parlement en de Raad van 27 april 2016 over het gebruik van persoonsgegevens van passagiers (PNR-gegevens) voor het voorkomen, opsporen, onderzoeken en vervolgen van terroristische misdrijven en ernstige criminaliteit, Pb.L. 4 mei 2016, afl. 119, 132 (hierna 'Richtlijn 2016/681'). 
een correlatie tussen de passagiersgegevens en de (inter)nationale gegevensbanken van rechtshandhavingsinstanties, anderzijds tracht de PIE een overeenkomst te detecteren tussen de passagiersgegevens en risicoprofielen die zijn samengesteld op basis van vooraf bepaalde criteria (Bollens \& Van der Auwera, 2021).

Met de ontwikkeling van 'risicoprofielen' wordt immers getracht om potentieel risicovolle passagiers aan te merken die niet noodzakelijkerwijze gekend zijn bij de rechtshandhavingsautoriteiten of opgenomen zijn in de genoemde gegevensbanken of geldende watchlists. Een nauwkeurige afbakening en bepaling van de vooraf vastgestelde evaluatiecriteria kunnen in sterke mate bijdragen tot de identificatie van personen op wie een 'redelijke verdenking' van betrokkenheid bij terrorisme of ernstige criminaliteit zou kunnen rusten (Van der Auwera \& Bollens, 2021). In dat verband worden passagiersgegevens door de PIE verwerkt, teneinde individuen te identificeren die voordien 'onbekend' waren en betrokken 'zouden kunnen' zijn bij terroristische activiteiten of ernstige criminaliteit (Enerstvedt, 2017). Ter illustratie kunnen in de criteria bijvoorbeeld bepaalde specifieke reserverings- of reisgegevens worden opgenomen (o.a. een ongebruikelijke reisroute, een bepaald land van bestemming of vertrek, de betaalmethode, de datum of het tijdstip van reservering of de naam van de reisoperator), die op zichzelf of in combinatie met elkaar aanleiding kunnen geven tot een risicovolle hit.

\subsubsection{Gedragsprofilering op luchthavens}

Tegenwoordig anticiperen luchthavens op een terroristische dreiging door allerhande nieuwe preventieve veiligheidsvoorzieningen, zoals het opleiden van rechtshandhavers tot behaviour detection officers (BDO's) (ook gekend als 'spotters'), wiens taak het is om verdacht of afwijkend gedrag vroegtijdig te detecteren bij high-risk passagiers aan de hand van een gedragsindicatorenlijst (Van der Auwera, Van Daele \& Vervaeke, 2017). Hun specifieke taak bestaat erin om volgens de leer van de predictive of behavioral profiling (ook gekend als de 'spotterstechniek' of gedragsprofilering) verdachte of afwijkende gedragingen op de luchthaven te detecteren en de potentiële dreiging ervan met gepaste maatregelen te neutraliseren. De BDO's wordt een confidentiële observatietechniek aangeleerd die zich in het bijzonder richt op de uiterlijke en gedragsmatige kenmerken van een 'criminele intentie'. De theorie van de gedragsprofilering stoelt namelijk op het principe dat passagiers met een criminele intentie door allerhande oncontroleerbare fysiologische processen 'afwijkend' gedrag zullen vertonen op stress-inducerende plaatsen (Price \& Forrest, 2016; Van den Berg et al., 2015; Mulder, 2014; Van Pel, 2012).

Tijdens de observatiefase focust men daarom op een omvangrijke lijst van non-verbale, verbale, paraverbale en psychofysiologische 'risico-indicatoren' die verwantschap vertonen met algemene tekenen van stress (o.a. oogcontact vermijden, geeuwen, zweten en/of sterke lijfgeur), angst (o.a. koude indringende blik, bagage stevig vasthouden, overmatige interesse in veiligheidspersoneel en/of houterig gedrag) en misleiding (o.a. verward lijken, niet antwoorden op vragen en/of een vermomming lijken te dragen) (Van der Auwera et al., 2018; Van den Berg et al., 2015; Van Rest et al., 2014). Eenmaal de BDO na een kortdurende observatie van de passagiersstroom oordeelt dat het gedrag van een bepaald persoon potentieel verdacht is (omdat verschillende gedragsindicatoren afwijken van de gangbare 
norm), zal men overgaan tot een informeel gesprek met de desbetreffende passagier. Naast het peilen naar de reden van zijn of haar aanwezigheid op de luchthaven, vraagt de BDO - via een aangeleerde security questioning methodiek - naar onverwachte zaken (zoals waar men heen gaat, waar men zal verblijven en met wie men reist) (Van Pel et al., 2012). Tijdens dit informele gesprek onderwerpt de BDO de passagier voor een tweede maal aan een gedragscontrole. Wanneer na deze conversatie nog steeds redelijke gronden aanwezig zijn om te geloven dat de passagier een misdrijf heeft gepleegd of er een zal plegen, kan men overgaan tot een extra fysieke controle van de passagier en zijn bagage (De Valk \& Aerdts, 2018; Price \& Forrest, 2016; Mulder, 2014).

\section{Enkele aandachtspunten en zogenaamde 'red flags'}

\subsection{De mythe van het causaal determinisme ontkracht}

In tijden waar alles draait rond risicoreductie en -inschatting, lijkt de neiging van rechtshandhavingsinstanties om de innerlijke gezindheid van personen te interpreteren groter te worden. Op enigszins chargerende toon beweren sommige academici daarom dat we ons begeven richting een onbetreden grensgebied tussen gedachte en gedraging, waar personen bij voorbaat als 'risicovol' of 'potentieel gevaarlijk' kunnen worden aanzien, zonder dat er daadwerkelijk sprake is van een redelijk vermoeden van schuld aan een strafbaar feit (McCulloch \& Pickering, 2009). Toegepast op het gebruik van risicoprofielen, zou dit concreet kunnen betekenen dat bepaalde groepen en subpopulaties die voldoen aan een bepaald risicoprofiel vanzelfsprekend als potentieel verdacht zullen worden beschouwd - althans 'tot het tegendeel bewezen is'. In het verlengde daarvan kan het (toevallig) betreden van een locatie, het behoren tot een zekere leeftijdscategorie of het bezitten van een bepaalde nationaliteit er bijvoorbeeld voor zorgen dat burgers die soortgelijke kenmerken vertonen aan eenzelfde beveiligingsregime worden onderworpen, ongeacht of ze concrete plannen hebben om een delict te plegen (Vandewalle et al., 2015).

In het licht van dit laatste vervalt volgens Schinkel (2009: 8) de klassieke tweedeling tussen repressie en preventie, vermits zich een nieuwe preventieve 'tussenvorm' heeft ontwikkeld met enkele uitgesproken repressieve eigenschappen. Deze tussenvorm - op treffende wijze 'prepressie' genoemd - wordt omschreven als 'een proactieve repressie die bepaalde vormen van leven vroegtijdig de kop in beoogt te drukken en tracht om te buigen in de richting van gewenste levensvormen'. In die proactieve denkwijze wordt ten onrechte uitgegaan van een deterministisch geloof in de onafwendbaarheid van ongewenst en gevaarlijk gedrag, wanneer eenmaal potentiële risico's zijn gesignaleerd. Vanuit deze beveiligingsideologie kunnen enkel vroegtijdige interventies de 'would-be' criminelen behoeden voor toekomstige handelingen die onveiligheid zullen veroorzaken (Schinkel, 2009; Schuilenburg, 2016; Van Brakel \& De Hert, 2011).

Niettemin is bovenstaande een misvatting. Het betreft hier een foutieve perceptie van causaliteit, aangezien een voorspelling aan de hand van risicoprofielen niet automatisch betekent dat iemand die voldoet aan het profiel ook effectief criminaliteit zal plegen; correlatie is met andere woorden niet hetzelfde als causaliteit 
(Swanborn, 2015; zie o.a. ook Spithoven \& Beerends, 2019). Zonder te beweren dat gebruikers van risicoprofielen op naïeve wijze geloven in het foutloze karakter van deze risicoprofielen, blijkt uit onderzoek dat louter kennis van het risicoprofiel er in de praktijk voor zorgt dat rechtshandhavingsinstanties de geprofileerde groep nog moeilijk onbevangen kunnen benaderen, in die zin dat 'they become just a little bit less disturbed, a little less troubled by the collateral consequences, precisely because they begin to perceive these groups as more criminal' (Harcourt, 2007: 189). De profieleigenschappen kunnen namelijk automatisch geassocieerd worden met dreiging, gevaar en zelfs criminaliteit, waardoor een zekere 'stereotiepe activatie' optreedt en men bijgevolg minder terughoudend blijkt te zijn om burgers met deze karakteristieken staande te houden en te onderwerpen aan een extra beveiligingscontrole (zie o.a. Jones \& Kaplan, 2003).

Het is daarom belangrijk te onderstrepen dat de output van risicoprofielen geen oorzakelijk verband, maar louter een relatieve mogelijkheid pretendeert, waaruit enkel indirecte en probabilistische conclusies kunnen worden afgeleid. Zelfs al voldoet iemand quasi volledig aan de voorwaarden van het opgestelde profiel, dan is het nog steeds niet gegarandeerd dat het verwachte criminele gedrag zich in de toekomst zal voordoen. Risicoprofielen hebben namelijk geenszins het vermogen om causale claims te formuleren of een causaal determinisme te pretenderen, laat staan om als legitieme vervanging voor zelfstandig bewijs te dienen of ander bewijs te versterken (Cavusoglu et al., 2010; Fuster et al., 2010; Lodder \& Schuilenburg, 2016). Precies dit onvermogen om accurate en causale uitspraken te doen, ondergraaft het utopisch verlangen om immer geldende en foutloze output te leveren. Het is net deze causale impotentie die onvermijdelijk leidt tot het aanmerken van een hoog aantal onschuldigen als verdacht (vals-positieven), terwijl tezelfdertijd criminelen niet altijd worden gedetecteerd (vals-negatieven) (Brown \& Korff, 2009).

\subsection{De vals-positieve aanduiding: accepteren of protesteren?}

In de praktijk is het zo dat de kans op het correct aanduiden van een crimineel (juist-positieven) vele malen kleiner is dan de waarschijnlijkheid op een vals-positief signaal (base-rate fallacy of low target base-rate) (zie o.a. Brown \& Korff, 2009; Cavusoglu et al., 2010). Een hypothetisch voorbeeld (tabel 1) waarbij risicoprofielen gebruikt worden op een luchthaven kan voor verduidelijking zorgen. Vermits van het grote aantal passagiers op een luchthaven slechts een klein aantal passagiers een criminele intentie bezit, kan het in theorie nuttig zijn om aan de hand van risicoprofielen de te controleren groep te verkleinen. Stel dat we vanuit een utopisch verlangen veronderstellen dat risicoprofielen in staat zijn om een opmerkelijke accuraatheid aan de dag te leggen door zowel passagiers met kwade bedoelingen als passagiers zonder criminele intenties in $90 \%$ van de gevallen correct te categoriseren, ${ }^{2}$ dan nog resulteert dit in de praktijk in een enorm hoog aantal vals-positieven (Honts \& Hartwig, 2014; Kleinberg \& Verschuere, 2019). Rekening gehouden met de prevalentie van een criminele intentie op een luchthaven (i.e. in studies doorgaans geschat op 0,01\% (Honts \& Hartwig, 2014)) en de hoge accuraatheid 
van $90 \%$, illustreert tabel 1 dat in een hypothetische passagierspopulatie van 100.000 personen zo'n 10.008 passagiers aangemerkt zullen worden als 'potentieel verdacht', waarvan 9999 passagiers uiteindelijk geen criminele intentie hebben (vals-positief). Dit maakt dat de feitelijke accuraatheid in dit fictieve voorbeeld amper $0,09 \%$ bedraagt, wat met andere woorden betekent dat iemand die wordt aangeduid door het risicoprofiel als 'verdacht' in amper 0,09\% van de gevallen ook effectief een criminele intentie bezit (juist-positief) en in 99,91\% van de gevallen onterecht een extra beveiligingscontrole dient te ondergaan (vals-positief). Zelfs indien de accuratesse van de risicoprofielen een astronomische nauwkeurigheid van $99 \%$ haalt, dan nog blijft het aantal juist-positieven laag (9\%) en de vals-positieve gevallen bijzonder hoog (91\%).

Vanuit een uitgangspunt waarbij risicoreductie centraal staat, is het echter niet realistisch bij profileringspraktijken een $100 \%$ succespercentage te veronderstellen. Daarbij dient te worden opgemerkt dat het cruciaal is om vooraf aan de profileringspraktijk een helder beschreven doel te stellen (bijv. risicoreductie of -uitsluiting). De prangende - en onzes inziens vanuit academisch perspectief onmogelijk te beantwoorden - vraag hierbij is dan waar het ideale evenwicht ligt tussen het succes- en het foutenpercentage én - daarmee samenhangend - vanaf wanneer de grootte van het foutenpercentage acceptabel is (Bollens \& Van der Auwera, 2021). Enerzijds zou men bij zware risico's (o.a. terroristische aanslagen) kunnen veronderstellen dat een hoog foutenpercentage bij profileringsmethoden wordt aanvaard, mits er minstens één 'zwaar risico' mee wordt voorkomen. Dit terwijl anderzijds bij minder impactrijke risico's (o.a. zakkenrollerij) de verhouding tussen het succes- en foutenpercentage een andere (vaak omgekeerde) weging krijgt. In het verlengde van die ambivalentie bestaat er onder academici immers de unanimiteit dat de maatregel die volgt op de voorspelling 'proportioneel' dient te zijn. Hiermee wordt concreet bedoeld dat 'de voordelen die we halen door het gebruik van risicoprofielen (o.a. reduceren van criminaliteit enz.)' moeten worden afgewogen tegen 'de hinder die de onschuldige burger hiervan ervaart' (o.a. privacy-schendingen, onveiligheidsgevoelens, discriminatie enz.) (zie o.a. Hasisi et al., 2019; Michaelsen, 2010). Echter, zelfs al weet men exact wat de voor- en nadelen zijn van het gebruik, dan nog is een rationele uitvoeringsbeslissing of afweging quasi onmogelijk objectief te maken. Het nemen van bepaalde beveiligingsmaatregelen op basis van voorspellingen en de daarbij horende afweging of deze 'proportioneel' zijn, zal namelijk altijd een bepaalde spanning vertonen, vermits steeds per individueel geval aan de hand van een normatief standpunt of intuitief besluit dient te worden bepaald of 'het gebruik ervan (wel of niet) gerechtvaardigd is in het licht van de kosten' (De Goede, 2011). De afweging die daarbij gemaakt zal worden, is steeds afhankelijk van de gangbare veiligheidscultuur (i.e. risicoreductie vs. risico-uitsluiting), het type misdrijf (o.a. terrorisme vs. zakkenrollerij), context (i.e. hoe ingrijpend is de beveiligingscontrole, hoeveel personen dient men te controleren enz.) of het land waarin de keuze moet worden gemaakt (i.e. wat moreel, juridisch en maatschappelijk verantwoord is op beveiligingsvlak, is vaak anders in Europa, de Verenigde Staten, Israël of Aziatische/Afrikaanse landen).

Gezien de huidige tijdsgeest worden wereldwijd alsmaar meer vals-positieve fouten door practici geaccepteerd vanuit een utilitaristische ratio: de onnauwkeurigheid 
van beveiligingshandelingen wordt immers gerechtvaardigd door de potentie die deze handelingen hebben op de algemene veiligheid van een grotere te beschermen groep. Hierbij valt bijvoorbeeld te denken aan (i) het inreisverbod dat voormalig president Trump in 2017 oplegde aan mensen uit bepaalde landen uit het Midden-Oosten om zich - naar eigen zeggen - beter te beschermen tegen terroristische aanslagen, (ii) de extra beveiligingsmaatregelen die Palestijnen vandaag in Israëlische luchthavens moeten ondergaan of (iii) de uitgebreide stop-and-search mogelijkheden in het Verenigd Koninkrijk om iemand zonder reden op straat te controleren (o.a. ID-controle en preventieve fouillering). Vanuit die logica is het namelijk verdedigbaar om onschuldige burgers staande te houden, te controleren en zelfs (tijdelijk) vast te houden, mits de potentieel schuldigen maar niet door de mazen van het net glippen (Van Brakel, 2015). Precies omdat in de maatschappij het angstwekkende beeld leeft dat niemand te vertrouwen is ("everybody is untrustworthy'), worden interventies vaak gelegitimeerd onder het motto: 'better to be safe than sorry' (Pleysier, 2013). Uit onderzoek blijkt bovendien dat rechtshandshavers geneigd zijn om de impact van preventieve controles op de burger als gering te beschouwen (i.e. 'tijdelijk ongemak' of 'vervelende onderbreking'), terwijl deze proactieve acties wel degelijk een indringend effect hebben op burgers. Naast het vertrouwen in de rechtshandhavingsinstanties, daalt ook de bereidheid om ermee samen te werken significant (Landman \& Kleijer-Kool, 2016). Anderzijds is de profileringsmethode vanwege de hierboven besproken notabele foutenmarge ook vaak aan kritiek onderhevig, temeer omdat vaak (i) enkel de 'succesverhalen' gebruikt worden om de effectiviteit aan te tonen en verder (ii) geen statistieken getoond (kunnen) worden waaruit de efficiëntie blijkt (namelijk hoeveel risico-inschattingen uitgevoerd werden én welk percentage daarvan daadwerkelijk correct/foutief was).

Tabel 1 Illustratie base-rate fallacy aan een accuraatheid van 90\%

\begin{tabular}{|c|c|c|c|}
\hline Indicatie risicoprofiel/Realiteit & $\begin{array}{l}\text { Personen met } \\
\text { criminele intentie }\end{array}$ & $\begin{array}{l}\text { Personen zonder } \\
\text { criminele intentie }\end{array}$ & $\begin{array}{l}\text { Populatieverde- } \\
\text { ling criminele } \\
\text { intentie } \\
\text { (0.01\% criminele } \\
\text { intentie) }\end{array}$ \\
\hline $\begin{array}{l}\text { Indicatie 'criminele intentie' } \\
\text { (accuraatheid) }\end{array}$ & $\begin{array}{l}9 \\
\text { (0,09\% } \\
\text { juist-positief) }\end{array}$ & $\begin{array}{l}\text { I } \\
\text { (0,01\% } \\
\text { vals-negatief) }\end{array}$ & $\begin{array}{l}10 \\
\text { (personen met } \\
\text { criminele } \\
\text { intentie) }\end{array}$ \\
\hline $\begin{array}{l}\text { Indicatie 'geen criminele intentie' } \\
\text { (accuraatheid) }\end{array}$ & $\begin{array}{l}9.999 \\
(99,91 \% \\
\text { vals-positief) }\end{array}$ & $\begin{array}{l}89.991 \\
(99,99 \% \\
\text { juist-negatief) }\end{array}$ & $\begin{array}{l}99.990 \\
\text { (personen } \\
\text { zonder criminele } \\
\text { intentie) }\end{array}$ \\
\hline Totaal & 10.008 & 89.992 & 100.000 \\
\hline
\end{tabular}

\section{3 (On)bewuste zelfbevestiging}

Systematisch een bepaalde (risico)groep viseren tijdens preventieve controles kan op lange termijn een pervers neveneffect creëren en bijgevolg leiden tot een zelfversterkend effect. Het vormgeven van risicoprofielen, en meer bepaald de keuze welke risicofactoren effectief worden opgenomen en bijgesteld, blijft per definitie 
in enigerlei mate subjectief (Van der Auwera \& Bollens, 2021). Wanneer passagiersinformatie-eenheden (zie par. 2.3.1) bijvoorbeeld herhaaldelijk risicogroepen aan een controle onderwerpen, lijkt het evident dat de datagegevens hierover zullen toenemen en de gecontroleerde personen bijgevolg steeds opnieuw als 'risicovol' uit de nieuwe statistische analyses zullen rollen. Dit betekent concreet dat wanneer per maand twintig vluchten uit Curaçao en één uit Japan aan een controle worden onderworpen, de kans op het vinden van criminelen afkomstig uit $\mathrm{Cu}$ raçao vele malen groter is dan die uit Japan, louter omdat de populatie om een crimineel te vinden op een vlucht vanuit Curaçao twintig keer zo groot is. Zelfs indien blijkt dat de correlationele veronderstellingen tussen het profiel en het plegen van criminaliteit incorrect zijn, nemen we een misleidende (maar vanzelfsprekende) toename waar van geregistreerde criminaliteit bij de aangemerkte risicogroep, want 'if you spend more time looking for crime in a subgroup, you will find more crime there; whom they catch depends on where they look' (Harris, 2002: 223-225). Dit onderliggende self-confirmation mechanisme (ratchet- of pal-effect) betekent dat risicoprofiling de correlatie tussen de risicokenmerken en criminaliteit onbewust accentueert (Harcourt, 2007). Doordat steeds gefocust wordt op dezelfde usual suspects, ontstaat er als het ware een stigmatiserende feedbackloop: eenmaal men als risicogroep wordt aanzien of gelabeld, zal men dit voor een lange tijd blijven, aangezien het bereiken van een bepaald risicoperceptie-niveau het proces quasi onomkeerbaar heeft gemaakt (Kaufmann et al., 2018; Schuilenburg, 2016).

\section{$4 \quad$ Noodzakelijke succesfactoren op lange termijn}

\subsection{De nood aan betrouwbare data}

Kritiek op het profileren is vaak niet zozeer gericht op de classificerende profilingsgedachte an sich, maar eerder op de gronden en data waarop het risicoprofiel steunt. Daar kan meteen bij worden opgemerkt dat de wetenschappelijk-statistische grond van de gebruikte risicoprofielen in de veiligheidssector in bepaalde situaties eerder zwak is. Dit is in het bijzonder het geval wanneer de gebruikte profielen ontstaan vanuit een professionele intuïtie en worden gebaseerd op percepties, opgebouwde ervaring of een zogenaamd buikgevoel van de rechtshandhaver (Dekkers et al., 2015; Dekkers \& Van der Woude, 2014). In de academische literatuur bestaat bijvoorbeeld onenigheid over de effectiviteit van de gedragsprofilering (zie par. 2.3.2). Enerzijds wordt geopperd dat het gebruik van BDO's op luchthavens een meerwaarde kan betekenen, zowel in videobewakingszalen als op het werkterrein. Anderzijds tonen de resultaten van een sociaal- en rechtspsychologische analyse dat de theoretische validiteit van de opgenomen gedragsindicatoren bijzonder zwak is en het menselijke vermogen inzake de dreigingsbeoordeling vele aandachtspunten bevat (Van der Auwera et al., 2021).

Het spreekt voor zich dat bij intuïtief vormgegeven profielen de kans bestaat dat het subjectieve beeld over de daderkenmerken niet strookt met de werkelijkheid. $\mathrm{Bij}$ predictieve risicoprofielen is het daarom cruciaal dat de risicofactoren gegrond zijn op voldoende betrouwbare informatie. Indien de profielen gevoed worden met vooroordelen ten aanzien van bepaalde groepen of geëxtraheerd worden uit onvolledige databestanden waarin fouten vervat zitten, zal dit logischerwijze het fou- 
tenpercentage doen toenemen en bijgevolg een negatief effect hebben op de kwaliteit van de voorspelling (De Vries \& Smit, 2016; Perry et al., 2013; Spithoven \& Beerends, 2019; WRR, 2016). De effectiviteit van deze profielen zal aldus fluctueren naargelang de volledigheid en betrouwbaarheid van de informatie waarop de risicoprofielen zich baseren: 'garbage in is garbage out'. Hiaten in de inputgegevens zullen met andere woorden resulteren in blinde vlekken in de output. Daarbij is aan te merken dat hoe meer relevante data ter beschikking worden gesteld, hoe geavanceerder een risicoprofiel kan worden vormgegeven en hoe meer het neigt naar een 'gepersonaliseerd' profiel, waardoor high- en low-risk passagiers op subtielere wijze onderscheiden kunnen worden (Schreurs et al., 2008).

\subsection{De nood aan feedback}

Risicoprofielen zijn succesvol in zoverre criminaliteit in de toekomst zal lijken op die in het verleden. In dat verband is het aanbevelenswaardig om voldoende follow-upgegevens bij te houden over preventieve controles om de data waarop de risicoprofielen steunen actueel te houden. Zonder passende inspanningen om risicoprofielen te beoordelen, moet elke bewering omtrent doeltreffendheid of efficiëntie met de nodige scepsis worden bekeken. Meten is immers de sleutel tot het vaststellen van vatbare verbeterpunten, zowel met betrekking tot het bepalen van de doeltreffendheid van de risicoprofielen als met betrekking tot het nemen van beslissingen over de toewijzing van middelen (Perry et al., 2013). Het is daarbij van wezenlijk belang dat de diensten die de risicoprofielen vormgeven afdoende feedback ontvangen van de rechtshandhavingsinstanties over het werkzame en doeltreffende karakter van de profielen (incl. informatie over het aantal vals-positieven). Het is onvoldoende om enkel de cijfers omtrent de juist-positieve gevallen door te geven, aangezien zo enkel op basis van absolute waarden een uitspraak kan volgen over de effectiviteit. Om een uitspraak te formuleren over de feitelijke accuraatheid van de risicoprofielen (i.e. juist-positieven delen door vals-positieven, zie par. 3.2), dient immers ook het aantal vals-positieve gevallen (i.e. gecontroleerd maar niets crimineel vastgesteld) te worden geturfd. Met het oog op het systematisch bijstellen van de bestaande risicocriteria lijkt het daarenboven meer dan nodig om kennis te hebben over de feitelijke accuraatheid van de bestaande risicoprofielen enerzijds, en nieuwe informatie aangaande recente criminaliteitstrends anderzijds (Bollens \& Van der Auwera, 2021).

\subsection{De nood aan gepaste interventiemethoden en -technieken}

Complementair aan de noodzaak van een accurate criminaliteitsprognose is het bovendien cruciaal dat een bepaalde interventiemethode en/of -techniek (die volgt op de output van de risicoprofielen) ook effect heeft op het doel dat men wil nastreven (o.a. criminaliteitsreductie, efficiënte inzet van middelen enz.). Bij het vormgeven van risicoprofielen moeten beroepsbeoefenaars zich daarom in het algemeen richten op het produceren van resultaten met een tactisch nut. Dit betekent concreet dat het risicoprofiel de eigenschap dient te hebben om de te controleren groep of het te controleren gebied in die mate te verkleinen, dat de controle ervan praktisch mogelijk is in het licht van de inzetbare middelen (Perry et al., 2013). Daarnaast kunnen risicoprofielen in theorie bijvoorbeeld accuraat zijn in het aanduiden 
van personen met een criminele intentie, maar tegelijk niet zo effectief of efficiënt blijken te werken in de preventie van criminaliteit. Zelfs de meest accurate risicoprofielen kunnen in principe nutteloos zijn wanneer er geen doeltreffende preventiestrategie voorhanden is om op de output te reageren (Smit et al., 2016). De reden voor dergelijke verminderde doeltreffendheid op vlak van criminaliteitspreventie kan bijvoorbeeld liggen in (i) de mogelijke weerstand die onder rechtshandhavers aanwezig is bij het gebruik van risicoprofielen, (ii) de niet aangepaste inzet van middelen, dan wel suboptimale inzet van rechtshandhavers, (iii) het optreden van een verplaatsings- of waterbedeffect ${ }^{3}$ of (iv) de verkeerde interpretatie en foutieve aanwending van de risicoprofielen (Van Brakel, 2015). Ook hier geldt de noodzaak om op herhaaldelijke wijze de huidige criminaliteitscijfers en data omtrent preventieve controles onder de loep te nemen, met dien verstande dat een adequate reactie van rechtshandhavers op risicopersonen en -groepen een positief effect kunnen hebben op de criminaliteitsgraad, in welk geval de aandacht en middelen wellicht beter op andere (nieuwe) groepen of locaties kunnen worden ingezet. Zoals reeds aangehaald, is het ook hier cruciaal om het aantal negatieve controles in de dataverzameling op te nemen, aangezien enkel op deze manier kan worden afgewogen of de doeltreffendheid (i.e. positieve controles afgewogen tegen de negatieve controles) afneemt, stagneert of toeneemt in de tijd. Wanneer een hotspot of risicogroep blijft bestaan, kan anderzijds bijvoorbeeld ook een alternatieve interventievorm worden overwogen.

\section{Besluit}

Iedereen bij de grenscontroles (o.a. luchthavens, treinstations enz.) grondig onderwerpen aan een uniforme screening is niet alleen inefficiënt of economisch oninteressant, maar ook praktisch onhaalbaar (o.a. tijds- en middelengebrek). Net omdat het aantal potentiële criminelen in de populatie bijzonder klein is en veiligheidsdreigingen slechts sporadisch voorkomen, dient gezegd dat de dagelijkse uitdaging van rechtshandhavers erin bestaat om de spreekwoordelijke 'speld in een hooiberg' te vinden. In het hierboven geschetste kader zijn risicoprofielen enorm waardevol voor grensposten, in het bijzonder omdat ze de theoretische potentie bezitten om aan te duiden in welk segment van de 'hooiberg' het best gezocht kan worden om de statistische kans op het vinden van de 'speld' te maximaliseren. Door systematisch aan de hand van een risicoprofiel de aangeduide personen te onderwerpen aan een beveiligingscontrole, bezit men namelijk het vermogen om met eenzelfde inspanning een hogere effectiviteit te halen (Van der Auwera \& Van Daele, 2019). Onzes inziens bezit het gebruik van risicoprofielen zeker een theoretische meerwaarde, mits de output met de nodige voorzichtigheid, kritische blik en nuance geïnterpreteerd alsook gecontroleerd wordt. Het stemt ons daarin tevreden dat ten tijde van de opkomst van automatische risicoprofilingsmiddelen (o.a. big data, algoritmische softwareprocessen enz.) de Europese wetgever beducht is voor deze

3 Het uitvoeren van extra controles op één bepaalde vlucht kan leiden tot een daling van het aantal criminelen op die vluchtroute in de toekomst, maar tot een stijging op andere vluchtroutes. Kortom, andere vluchtroutes worden de dupe van een bepaalde 'effectieve' maatregel. 
rijzende problemen en daarom voldoende waarborgen voorziet die kunnen verzekeren dat de voorafgaande beoordeling niet uitsluitend berust op geautomatiseerde middelen. ${ }^{4}$ Gezien de gedegen kans op missers ${ }^{5}$ lijkt de verplichting inzake de bevestiging van de logica van geautomatiseerde besluiten door een menselijke controle onzes inziens dan ook geen overbodige luxe te zijn. Cruciaal daarbij is dat de 'humans in the loop' niet vervallen in een vorm van 'data bijziendheid' (zie o.a. Spithoven \& Beerends, 2019) en steeds met voldoende kritische blik naar de hits kijken, waarbij ze zowel het verwerkingsproces waarlangs de voorspellingen tot stand komen als de resultaten daarvan - geval per geval - in vraag moeten durven stellen (Van der Auwera \& Bollens, 2021).

Ondanks dat er weinig duidende statistieken ter beschikking worden gesteld omtrent de efficiëntie en effectiviteit van risicoprofielen, is bovendien geweten dat het risico op zowel vals-positieve als vals-negatieve resultaten reëel is. ${ }^{6}$ De succesvolle werking hangt namelijk af van de volledigheid en betrouwbaarheid van de informatie waarop de risicoprofielen zich baseren. Wanneer de risicoprofielen niet representatief dan wel te breed of te eng zijn samengesteld, zal dit evident een negatief effect hebben op de effectiviteit én efficiëntie. Het lijkt daarenboven ook aangewezen dat een risicoprofiel per misdrijftype ontstaat, aangezien het profiel van een terrorist die de jihadistische ideologie aanhangt doorgaans anders is dan dat van individuen die de intentie hebben om fiscale fraude te plegen, drugs te smokkelen of kinderprostitutie te vergemakkelijken (Bollens \& Van der Auwera, 2021).

Hoe dan ook is het niet realistisch om te verwachten dat iedere crimineel zal worden tegengehouden door het gebruik van risicoprofielen. Niettemin blijkt de toepassing van risicoprofiling - op basis van de huidige inlichtingen - op luchthavens alreeds een behoorlijke afschrikkingswaarde bij terroristen te induceren. Criminelen maken vandaag namelijk vaak gebruik van zogenaamde 'voorafgaande test runs', teneinde na te gaan of (i) ze tot een bepaald risicoprofiel behoren of niet en (ii) welk gedrag op grensposten wordt opgemerkt (Homeland Security, 2015; Mulder, 2014; Chakrabarti \& Strauss, 2002). Bovendien blijkt uit recente terroristische bulletins ook dat Islamitische Staat in Irak en Syrië begonnen is met het instrueren

4 Zie o.a. in art. 7, zesde lid Richtlijn (EU) 2016/681.

5 De Europese Commissie gaf aan dat de Europese PIE's in 2018 via geautomatiseerde systemen gemiddeld $0,25 \%$ van alle passagiers van wie de passagiersgegevens zijn verzameld, aanduidde als een 'hit', terwijl uiteindelijk slechts $0,04 \%$ werd gevalideerd na een menselijke controle door PIE-medewerkers als 'potentieel te onderzoeken'. In 2019 werd 0,59\% van de passagiers aangeduid als 'hit', waar er na menselijke controle binnen de PIE nog 0,11\% overbleven als 'potentieel te onderzoeken'. Ter indicatie bedroeg de foutenmarge in 2018 en 2019 respectievelijk 84\% en 81\%. Hierbij dient daarenboven te worden aangemerkt dat er ook nog een bijkomende foutenmarge schuilt in de aanduiding van een potentieel verdacht individu, aangezien niet elke gevalideerde positieve overeenkomst uiteindelijk een crimineel blijkt te zijn na controle van de rechtshandhavingsautoriteiten op het werkterrein (o.a. luchthaven, station etc.). (Commission staff working document (Comm.). Accompanying the report from the Commission to the European Parliament and the Council on the review of Directive 2016/681 on the use of passenger name record (PNR) data for the prevention, detection, investigation and prosecution of terrorist offences and serious crime, 24 juli 2020, SWD(2020)128 def, 28).

6 Ter indicatie: in 2020 kruisten Belgische politiediensten 46 verschillende risicoprofielen met de passagiersgegevens van reizigers op Belgische luchthavens, wat uiteindelijke leidde tot 644 controles, waarvan uiteindelijk 431 een positief resultaat opleverden (i.e. succesratio van ongeveer $67 \%$ ) (Bové, 2021). 
van leden over mogelijke methoden om niet opgemerkt te worden door rechtshandhavingsautoriteiten (incl. BDO's) tijdens grenscontroles (Homeland Security, 2015).

Het gebruik van risicoprofielen moet daarom beschouwd worden als een waardevolle 'supplementaire beveiligingsmethodiek' (vooral inzake de grenscontrole én ter beveiliging van kritieke of vitale infrastructuur) die - als onderdeel van een omvangrijk en gelaagd beveiligingsapparaat - noodzakelijkerwijs moet worden toegepast in combinatie met andere beveiligingsmethodieken. Het is niets nieuws, noch wereldschokkend, wanneer wij prediken om meerdere en diverse beveiligingsmaatregelen te nemen in een gelaagde beveiligingscontrole, waardoor potentiële criminelen enerzijds meer inspanning moeten verrichten of een verhoogd risico lopen en anderzijds hun voordelen en mogelijkheden gereduceerd zien (zie Clarke \& Newman, 2006).

Kortom, het gebruik van risicoprofielen moet hoe dan ook beschouwd worden als een valabele beveiligingsmethodiek, indien voldoende rekening wordt gehouden met de noodzakelijke succesfactoren en de eerder beschreven valkuilen. Voldoet men evenwel niet aan deze voorwaardelijke eisen, dan is de kans groot dat de risicoprofiling aan grensposten inaccuraat is en aldus moet worden aanzien als een 'risicovolle profiling'?

\section{Literatuur}

Bauman, Z. (2013) Liquid Life. Cambridge: Polity Press.

Bollens, S. \& J. Van der Auwera (2021) De verwerking van passagiersgegevens door de Belgische passagiersinformatie-eenheid: een analyse van het Europees en Belgisch juridisch kader. Politie \& Recht, 4(1), 4-20.

Bové, L. (2021) Veiligheidsdiensten screenen meer dan 8 miljoen vliegtuigpassagiers, De Tijd, www.tijd.be/politiek-economie/belgie/algemeen/veiligheidsdiensten-screenenmeer-dan-8-miljoen-vliegtuigpassagiers/10298763.

Brown, I. \& D. Korff (2009) Terrorism and the Proportionality of Internet Surveillance. European Journal of Criminology, 6(2), 119-134.

Bruinsma, G., W. Bernasco \& H. Elffers (2010) Ruimtelijke verplaatsing van criminaliteit: Theorie, methodologie en empirie. In: E. Muller (red.), Criminaliteit: Criminaliteitsbestrijding in Nederland (p. 375-396). Alphen aan den Rijn: Kluwer.

Castel, R. (2003) L'insécurité sociale: qu'est-ce qu'être protégé? Paris: Seuil.

Cavusoglu, H., B. Koh \& S. Raghunathan (2010) An Analysis of the Impact of Passenger Profiling for Transportation Security. Operations Research, 58(5), 1287-1302.

Chakrabarti, S. \& A. Strauss (2002) Carnival booth: An algorithm for defeating the computer-assisted passenger screening system. First Monday, 7(10), 1-30.

Clarke, R. \& G. Newman (2006) Outsmarting The Terrorists. Westport: Greenwood Press.

De Goede, M. (2011) European security culture: Preemption and precaution in European security. Amsterdam: Amsterdam University Press.

7 Een diepgaande reflectie op het kostenplaatje van de risicoprofiling, de privacy-kwesties, de invloed van vele psychologische mechanismen én het gevaar inzake het gebruik van etnische profileringspraktijken overstijgt deze bijdrage (zie over dit laatste bijvoorbeeld wel Van der Auwera \& Van Daele, 2019). 
De Valk, G. \& W. Aerdts (2018) Inlichtingenwerk vanuit een methodologisch perspectief. Justitiële verkenningen, 44(1), 114-132.

De Vries, A. \& S. Smit (2016) Predictive policing: politiewerk aan de hand van voorspellingen. Justitiële verkenningen, 42(3), 9-22.

Dekkers, T., J, van der Leun \& M. van der Woude (2015). 'Driving while black'. Lessen en inzichten uit Amerikaans onderzoek naar racial profiling. In: L.G. Moor, J. Janssen, M. Easton \& A. Verhage (red.), Ethnic profiling en interne diversiteit bij de politie (p. 109-146). Antwerpen: Maklu.

Dekkers, T. \& M. van der Woude (2014) Staring at the felony forest? De complexiteit van risicoprofilering nader in kaart gebracht. PROCES, 93(1), 52-70.

Enerstvedt, O. (2017) Aviation Security, Privacy, Data Protection and Other Human Rights: Technologies and Legal Principles. Cham: Springer.

Furedi, F. (2018) How fear works: Culture of fear in the twenty-first century. Londen: Bloomsbury Publishing.

Fuster, G., S. Gutwirth \& E. Ellyne (2010) Profiling in the European Union: A High-Risk Practice. Inex Policy Brief, 10, 1-11.

Harcourt, B. (2007) Against Prediction: Profiling, Policing, and Punishing in an Actuarial Age. Chicago: University of Chicago Press.

Harris, D. (2002) Profiles in Injustice: Why Racial Profiling Cannot Work. New York: New Press.

Hasisi, B., S. Perry \& M. Wolfowicz (2019) Counter-terrorism effectiveness and human rights in Israel. In: E. Shor \& S. Hoadley, International human rights and counter-terrorism (p. 409-429). Switzerland: Springer.

Hildebrandt, M. (2008) Defining Profiling: A New Type of Knowledge? In: M. Hildebrandt \& S. Gutwirth (eds.), Profiling the European Citizen: Cross-Disciplinary Perspectives (p. 1745). Dordrecht: Springer.

Homeland Security (2015) Scientific Substantiation of Behavioral Indicators. Washington D.C.: Department of Homeland Security - TSA.

Honts, C. \& M. Hartwig (2014) Credibility assessment at portals. In: D. Raskin, C. Honts \& J. Kircher (eds.), Credibility assessment (p. 37-61). Oxford: Elsevier.

Janssen, J. (2014) Profileren en selecteren: efficiëntie of discriminatie? PROCES, 93(1), 3-6.

Jones, C. \& M. Kaplan (2003) The Effects of Racially Stereotypical Crimes on Juror Decision-Making and Information-Processing Strategies. Basic and Applied Social Psychology, 25(1), 1-13.

Kaufmann, M., S. Egber \& M. Leese (2018) Predictive Policing and the Politics of Patterns. The British Journal of Criminology, 59(3), 674-692.

Kleijer-Kool, L. \& W. Landman (2016) Boeven vangen: Een onderzoek naar proactief politieoptreden. Apeldoorn: Politie \& Wetenschap.

Kleinberg, B. \& B. Verschuere (2019) Being Honest About Deception Detection: between popular idea and scientific evidence. Aviation Security International, 25(2), 20-23.

Lodder, A. \& M. Schuilenburg (2016) Politie-webcrawlers en predictive policing. Computerrecht, 3, 150-154.

Lyon, D. (2003) Surveillance as Social Sorting: Computer Codes and Mobile Bodies. In: D. Lyon (ed.), Surveillance as Social Sorting: Privacy, Risk, and Digital Discrimination (p. 1330). Londen: Routledge.

Mali, B., C. Bronkhorst \& M. den Hengst (2017) Predictive policing: lessen voor de toekomst. Een evaluatie van de landelijke pilot. Apeldoorn: Politieacademie.

McCulloch, J. \& S. Pickering (2009) Pre-Crime and Counter-Terrorism: Imagining Future Crime in the 'War on Terror'. The British Journal of Criminology, 49(5), 628-645.

Michaelsen, C. (2010) The proportionality principle, counter-terrorism laws and human rights. City UHKL Review, 2, 19-43.

Mulder, P. (2014) Predictive Profiling Terrorisme: Praktische handleiding voor het toepassen van proactieve beveiliging bij islamitisch terrorisme. Almere: Trio SMC. 
Muller, E. (2006) Uitdagingen in de veiligheidszorg. In: F. Michiels \& E. Muller (eds.), Handhaving. Bestuurlijk handhaven in Nederland (p. 357-384). Deventer: Kluwer.

Peeters, R. \& M. Schuilenburg (2018) Machine justice: Governing security through the bureaucracy of algorithms. Information Polity, 23, 267-280.

Perry, W., B. McInnis, C. Price, S. Smith \& J. Hollywood (2013) Predictive policing. The role of crimeforecasting in law enforcement operations. Santa Monica: RAND Corporation.

Petherick, W. \& B. Turvey (2011) Criminal Profiling: Science, Logic, and Cognition. In: B. Turvey (ed.), Criminal Profiling: An Introduction to Behavioral Evidence Analysis (p. 4166). New York: Elsevier.

Pleysier, S. (2012) Kind als gevaar: De nieuwe preventie en criminalisering van gedrag. Tijdschrift voor Jeugd- en Kinderrechten, 4, 278-288.

Pleysier, S. (2013) Kinderen als 'crash test dummies'. Keerzijde van de lokroep naar vroegtijdige interventie. Tijdschrift voor Jeugd- en Kinderrechten, 3, 252-265.

Price, J. \& J. Forrest (2016) Practical Aviation Security: Predicting and Preventing Future Threats. Oxford: Elsevier.

Ratcliffe, J., T. Taniguchi, E. Groff \& J. Wood (2011) The Philadelphia foot patrol experiment: A randomized controlled trial of police patrol effectiveness in violent crime hotspots. Criminology, 49(3), 795-831.

Schinkel, W. (2009) De nieuwe preventie. Actuariële archiefsystemen en de nieuwe technologie van de veiligheid. Krisis, 2, 1-21.

Schreurs, W., M. Hildebrandt, E. Kindt \& M. Vanfleteren (2008) Cogitas, Ergo Sum. The Role of Data Protection Law and Non-discrimination Law in Group Profiling in the Private Sector. In: M. Hildebrandt \& S. Gutwirth (eds.), Profiling the European Citizen: Cross disciplinary perspectives (p. 241-270). Dordrecht: Springer.

Schuilenburg, M. (2016) Predictive policing: De opkomst van een gedachtenpolitie? Ars aequi, 65(12), 931-936.

Smit, S., A. de Vries, R. van der Kleij \& H. van Vliet (2016) Van Predictive naar Prescriptive Policing: Verder dan vakjes voorspellen. Den Haag: TNO.

Spithoven, R. \& S. Beerends (2019) Veiligheid uit de glazen bol?. Tijdschrift voor Veiligheid, 18(3/4), 75-92.

Svensson, J., H. Sollie \& S. Saharso (2011) Proactief handhaven en gelijk behandelen. Apeldoorn: Politie \& Wetenschap.

Swanborn, P. (2015) Basisboek sociaal onderzoek. Amsterdam: Boom Lemma Uitgevers.

Tierney, K. (2020) The Social Roots of Risk. Redwood City: Stanford University Press.

Van Brakel, R. (2015) Iedereen verdacht? De effectiviteit en impact van het gebruik van preëmptieve surveillance voor publieke veiligheid. Orde van de Dag, 69, 35-42.

Van Brakel, R. \& P. De Hert (2011) Policing, surveillance and law in a pre-crime society: Understanding the consequences of technology based strategies. In: E. De Pauw, P. Ponsaers, P. Deelman, K. Van de Vijver \& W. Bruggeman (eds.), Technology-led policing (p. 163192). Antwerpen: Maklu.

Van den Berg, H., R. Wijn \& D. van Hemert (2015) Gedragsprofiling: het bepalen van kwade bedoelingen en het meten van effectiviteit. Tijdschrift voor Veiligheid, 14(2), 3-18.

Van der Auwera, J. \& S. Bollens (2021) Op zoek naar de perfecte match: een juridisch-criminologische reflectie op de screening door de Belgische passagiersinformatie-eenheid. In: M. Bourguignon, T. Hick, S. Royer \& W. Yperman (eds.), Technology and society: the evolution of the legal landscape (p. 125-163). Oud Turnhout: Gompel \& Svacina.

Van der Auwera, J. \& D. Van Daele (2019) Risicoprofilering op de luchthaven: een juridische verkenning van de legitimiteit van etnische risicoprofielen. Tijdschrift voor Mensenrechten, 2019(4), 9-14.

Van der Auwera, J., D. Van Daele \& G. Vervaeke (2017) Een rechtspsychologische en mensenrechtelijke reflectie op de inzet van behaviour detection officers op luchthavens: heiligt het doel de middelen?. Gepresenteerd op het NVC-Congres, Leiden. 
Van der Auwera, J., D. Van Daele \& G. Vervaeke (2018) Predictive profiling as a new counter-terrorism measure at Belgian airports. The reliability and validity of the predictive profiling method: preliminary results and future research. Gepresenteerd op de International Conference on Behavioural and Social Sciences in Security (BASS 18), Lancaster.

Van der Auwera, J., D. Van Daele \& G. Vervaeke (2021) (Niet) getest en goedgekeurd? De vroegtijdige detectie van een criminele intentie op luchthavens door middel van gedragsprofilering: reflecties aangaande de theoretische validiteit en bruikbaarheid. Gepresenteerd op het NVC-Congres, Leiden.

Van der Woude, M. \& J. van der Leun (2013) De Nederlandse veiligheidscultuur als katalysator voor etnisch profileren? Tijdschrift over Cultuur \& Criminaliteit, 3(2), 123-136.

Van der Woude, M. \& E. Van Sliedregt (2007) De risicosamenleving: overheid vs. strafrechtswetenschap? Aanwijzingen voor het debat rondom veiligheid en risico's. PROCES, 6 , 216-226.

Van Pel, B. (2012) Predictive profiling, of proactief beveiligen: Beveiligingsmethodiek van nu. Security Management, 7/8, 38-41.

Van Pel, B., B. Verhagen \& R. Wijn (2012) Predictive profiling of proactief beveiligen: Security questioning \& Prikkelen. Security Management, 9, 40-43.

Van Rest, J., M. Roelofs \& A. van Nunen (2014) Afwijkend Gedrag: Maatschappelijk verantwoord waarnemen van gedrag in context van veiligheid. Den Haag: TNO.

Vandewalle, G., E. De Pauw, J. Vincent \& S. De Kimpe (2015) Gedigitaliseerde veiligheid vanuit het surveillanceperspectief? Orde van de Dag, 69, 6-16.

Whitaker, R. (2011) Behavioural profiling in Israeli aviation security as a tool for social control. In: E. Zureik, D. Lyon \& Y. Abu-Laban (eds.), Surveillance and Control in Israel/Palestine: Population, territory, and power (p. 371-385). New York: Routledge.

WRR (2016) Big Data in een vrije en veilige samenleving. Amsterdam: Amsterdam University Press.

Zedner, L. (2007) Pre-crime and post-criminology? Theoretical Criminology, 11(2), 261-281. 